Special Issue on Federalism and Conflict Management edited by Neophytos Loizides, losif Kovras and Kathleen Ireton.

\title{
RUSSIAN FEDERALISM AND TATARSTAN'S ETHNIC PEACE
}

\author{
by Christopher Barker
}

*Queen's University Belfast
Email: cbarker04@qub.ac.uk

\begin{abstract}
This article focuses on cooperation between Muslims and Christians in Tatarstan and illustrates how federal arrangements operate to diffuse ethnopolitical crises. Management of ethnic and national conflicts has importance within Russia and its immediate neighbourhood as well as globally. Using news reports, secondary sources, and interviews from fieldwork in Russia, the article identifies ways in which the two communities are working together to ensure stability and peace in the region. It examines the religious aspects of cooperation, as well as economic and political dimensions of cooperation. The article identifies lessons for the rest of Russia, particularly Chechnya as well as the central Asian states formerly part of the Soviet Union. Even though federalism has got negative publicity in former communist countries, particularly following the collapse of communism, the case of Tatarstan suggests ways through which federal institutions enable cooperation between Russians and Tatars. In addition, the article considers recent pitfalls the two sides have had to overcome and broader implications for federalism and reconciliation studies in general.
\end{abstract}

Keywords: Russia, Tatarstan, Ethnic peace

Barker, C. 2011, "Russian Federalism and Tatarstan's Ethnic Peace”, Federal Governance, vol. 8 no. 2, pp. 42-53. 


\section{About Federal Governance}

Federal Governance is an online graduate journal on theory and politics of federalism and multilevel governance. Its mandate is to engage the global federalism community and reach out to outstanding graduate students interested in federalism and multi-level governance. By providing a platform for graduate students to have early success in their careers, Federal Governance seeks to promote and sustain interest in federalism and multi-level governance research among graduate students. Allied with the Forum of Federations and founding partner, Institute of Intergovernmental Relations at Queen's University; Federal Governance aims to contribute to a global dialogue on federalism.

Co Chairs, Advisory Committee:

Publisher:

Managing Editor:

Associate Editors:
Rupak Chattopadhyay and Christian Leuprecht

Forum of Federations

(Rupak Chattopadhyay and Rod Macdonell)

Annegret Eppler

Joshua Cerovski, Dominic Heinz,

Eva-Maria Maggi and Victoria Tait

\section{Terms of Use}

Your use of this Federal Governance article indicates your acceptance of Federal Governance's Terms and Conditions of Use, available at www.federalgovernance.ca/terms. Federal Governance's Terms and Conditions of Use provides that you may use Federal Governance content only for personal, academic and non-commercial use. Each copy of any part of this Federal Governance article must contain the same copyright notice that appears on the screen or printed page of such transmission. 


\section{Introduction}

"When the Tatars were in charge, they acted like monsters. They stole from the Russians." A Russian friend said that to me while I was in Nizhny Novgorod visiting. The time of the Tatar Yoke-the three centuries preceding Ivan the Terrible's $16^{\text {th }}$ century conquest of the area that became Tatarstan-left an indelible mark upon the Russian psyche. For their part, Tatars remember the time of Ivan's conquest as an age of forced conversion, destroyed mosques, and "Tatar suburbs"-areas akin to the ghettos of Eastern Europe and the projects of the United States where Tatars were forced to live (Mukhetdinov 2010). These two ethnic groups have historically been adversaries, and their cultural memory shows it. But today they share space within Russia peacefully, a model of cultural accommodation. The vast majority of ethnic Russians are Orthodox Christians, culturally if not religiously; the Tatars are the largest Muslim ethnic group living within the Russian Federation.

Russia is not without violent conflict, with Islamic separatists in Chechnya, Dagestan, and Ingushetia all occupying much of the Russian government's attention. In this context it is remarkable how peaceful inter-ethnic relations between Tatars and Russians are. The popular imagination holds that Western societies cannot coexist with Islamic ones, and that when Islam encounters other religious or cultural ideologiesparticularly Western or Christian ones-that conflict inevitably follows. While being interviewed Firdaus Vagapova mentioned a poll conducted in the 1990's that asked Tatars and Russians about their attitudes towards each other, and the results of the poll showed that Tatars and Russians were actually highly favourably inclined towards each other (Vagapova 2010). How then, do Tatars and Russians retain such good relations in the face of numerous historical reasons to be antagonistic? The answer is predictably complicated, and the reasons are difficult to separate from each other; but a combination of Soviet urban policy, open religious dialogue, broad federal autonomy, and a local emphasis enabled by Russia's federal government on shared cultural history and values keeps the peace between Russians and Tatars.

\section{Mutual Subjugation}

The story starts far earlier than one might believe. In 1228 the Mongols moved through what became the Russian heartland and conquered everyone in their path. At this time the Tatars did not exist as they currently conceive of themselves; instead they called themselves the Bulgars. When the Mongols invaded they were not yet Muslim, but the Bulgars were. After the Mongols converted in the 13th century, the Bulgars were ideally placed to help administer the conquered area. This is the moment that the Mongol yoke became the Tatar Yoke in the eyes of Russians (Hunter 2004, 144). Over time the Bulgars and the Mongols merged together to become what are now known as the 
Tatars, and they controlled European Russia until the 16th century when Ivan the Terrible began the expansion of the Russian Empire, defeating the Tatars decisively at Kazan. ${ }^{1}$

In 1552 the Russians finally captured Kazan, having fought a concentrated campaign for most of the year to achieve victory. This signaled the end of Tatar independence, and from then on they were to be subjects within the border of an imperial Russia, Ivan IV having established the patterns of Russian rule over its Muslim subjects for the next four and a half centuries (Pelenski 1974, 46). Both Moscow and Kazan hold lasting monuments to this conquest, with St. Basil's in the Red Square of Moscow being built to commemorate Ivan's victory, and the buildings of Kazan's kremlin rebuilt to reflect Russian sensibilities. Between 66,000 and 100,000 Russians-by default, "Christians"-- were "liberated" from Kazanian hands during the course of the conquest. Providing for their safety had been another motivation for the fighting, at least outwardly (Pelenski 1974, 238).

The period directly after Russian conquest was not exactly easy for the Tatars. Modern day Kazan boasts a beautiful canal running through the city near the Kremlin. Today this canal is a quaint, romantic walk near the bustling economic heart of the city. Its construction, however, was akin to the "Peace Walls" of Belfast, with the canal signifying the line between the area the Russians lived in and the "Tatar suburbs." From the beginning, despite Imperial pro-Orthodox/Russian policy and rhetoric, the Tatars and the Russians enjoyed a good deal of cooperation after the Russian conquest, at least among the elites. Before too long Tatar elites had assumed fairly powerful roles within Russian society. The attitude towards common Tatars was considerably less magnanimous, though. Some were even deported, to the north to work on Russia's naval fleet (Akiner 2005, 57).

The Russians made a concerted effort to convert and Christianize the Tatars. Those who did convert were called Kryashen, and over time came to be seen as an entirely different people group within the region. Still, though, the Tatars did not convert en masse. Bukharaev thinks that part of the reason Kazanians did not convert is that they had no real economic or political incentive to do so (Bukharaev 2000, 292). Russians were always given the most important jobs in the region, and those jobs that were made available to the Tatar elite were available regardless of religion. Over the course of the next two centuries things remained difficult for the Tatars. Catherine the Great eased the restrictions on the Tatars somewhat, and even allowed an assembly to form with jurisdiction over religious and civil matters. Things weren't perfect, and even

1 Kazan is the capitol of what would become Tatarstan. St. Basil's Cathedral in Moscow's Red Square was constructed to commemorate Ivan the Terrible's victories over the Tatars, culminating in the conquest of Kazan. The church's domes each represent a victory in the Tsar's campaign. 
after the emancipation of serfs, some Tatars chose to immigrate to Turkey rather than stay in Russia (Akiner 2004, 58).

\section{National Consciousness and Soviet Rule}

In 1910, only 182,653 people lived in Kazan. Of these, only 30,486 were Tatar (Rorlich $1986,77)$. One hundred years later, more than one million people live in Kazan, with a roughly equal ethnic split. This follows the general pattern of Soviet demographics. During the eighty years of Soviet rule the entire USSR urbanized at an impressively quick pace. Tatarstan was no exception, and by the time the USSR fell apart the republic had changed from a rural to an urban, industrialized area. The transition from urban to rural was eased somewhat by the presence of the Jadids, Islamic reformers whose influence will be explained in greater depth below, but many of the normal effects of urbanization, combined with Soviet anti-religious policy, kept conflict to a minimum. Anti-religious persecution did not acknowledge creedal lines, so Muslims were repressed just as Christians were. As a result, a certain amount of solidarity emerged among religious Tatars and religious Christians. Professor Vagapova said while being interviewed, "A religious Orthodox Russian is closer to me than a nonreligious Tatar." (Vagapova2010).

Atheist propaganda was not the most effective policy for dampening Tatar identity at any rate, since prior to their conception of themselves as "Tatar" the Tatars had seen themselves as "Muslim." Gordon Hahn traces the beginnings of entrenched, selfconscious Tatar nationalism to the reforms of the Jadid movement, which had as its initial goal the improvement of education, but eventually went far further than that. The Jadids can be understood in the larger intellectual context of the Russian Empire at the time, as the decade they emerged in was a highly rationalist/modernizing one. They won an internal battle with the Qadimists, who were more traditional (Hahn 2007, 176177). Rorlich notes "the early Tatar reformers approached Islam not only as a religion but also as a culture that united the spiritual and temporal on a religious foundation." (ibid., 104) Even as the Tatars embraced their own literary language in the $19^{\text {th }}$ century, urbanized during the $20^{\text {th }}$ century, they found themselves persecuted by the authorities for their religious beliefs, they did not give up the idea of Islam as fundamental to their national, Tatar identity. Indeed, Rorlich notes "the move toward a Tatar literary language was also perhaps the key point in the transition from a purely Islamic identity to a still-Islamic, but also national, Tatar identity" (ibid., 67).

A final consequence of Soviet policy was the marginalization and elimination of internal dissent. In this sense, the Tatars and Tatarstan in particular were not much different from the rest of the USSR. During the Revolution the Bolshevik movement managed to arrest or cause the flight of many of the top nationalists/separatists in Tatarstan, which undoubtedly set back any sort of nationalist movement by decades and contributed to the generally peaceful relations between Christians and Muslims 
(Rorlich 2007, 133). With the loudest separatist voices gone, and Christian and Muslim alike discriminated against by the Soviet regime, neither side could afford to indulge in petty conflict with the other. Instead of arraying themselves against Russian Christians, the Tatars directed their energy at the Communist Party. The local party, controlled by Sultan Galiev, was a constant irritant to the Soviet administration. Even in embracing Communism in Tatarstan, Galiev's followers retained a distinctly Tatar, thus Muslim, identity, going so far as to release a statement decrying the proletariat of the revolution for failing to treat minority groups with equality (Bennigsen \& Lemercier-Quelquejay 1967, 114-115). ${ }^{2}$

Tatar leaders were able to keep a hold of their people's identity, even in the face of increased Soviet pressure, and even attained for themselves a measure of autonomous control. However, the creation of the Tatar Autonomous Soviet Socialist Republic (ASSR) didn't solve all the post-revolution problems, since the boundaries of the ASSR were arbitrarily drawn, leaving a majority of Tatars residing outside the boundaries of the Republic (Rorlich 1986, 138). Indeed, the simultaneous creation of the Bashkir ASSR was an attempt to cripple the Tatar nationalist movement within the Soviet Union by stranding a large number of Tatars outside the boundaries of their own ASSR (Bennigsen \& Lemercier-Quelquejay 1967, 126). Rorlich describes post-World War II Tatarstan as a model of "cultural resilience," with the Tatars clinging determinedly to their heritage (ibid., 157). Rorlich even points to the comparative strength if Islam, in particular a brand of Sufism, in Tatarstan as an example of the group's reaction to "the sterile and impersonal nature of a secular doctrine imposed from above." (ibid., 165). Despite the best efforts of the Soviet authorities, the creation of the ASSR, now the Republic of Tatarstan, gave the Tatars unprecedented control over their domestic affairs.

\section{The Federal 1990s}

President of the Republic, Mintimer Shaimiev, took advantage of the reforms of Perestroika to secure for the region even more autonomy, so that at the height of its privileges, it functioned in a way analogous to Scotland in the United Kingdom. These powers have been scaled back in recent years due to the reforms of Vladimir Putin, but Tatarstan is still allowed a great deal of autonomy in conducting its affairs. One particularly important piece of autonomy that the Tatars have won for themselves is the right to use their language in official business in the Republic. The number of Tatar language schools in Tatarstan and the surrounding regions has grown by leaps and bounds over the past twenty years (Vagapova 2010). Tatars enjoy a significant

2 The statement, quoted in its entirety herein, is worth reading all the way through, if only for its audacity. 
numerical advantage within their republic, but it isn't so great that the desires of the Russian minority can be ignored. ${ }^{3}$ Additionally, the area of Tatarstan is very rich in natural resources, making it an industrial centre within Russia. This continuous flow of capital has ensured that the region has stayed prosperous, particularly in comparison to the more isolated Islamic Republics within Russia.

"(Raphael) Khakimov pointed out that in Russia democracy was understood merely as a voting procedure which determines the majority opinion. Since Russians constitute 82 per cent of the Russian Federation's populations, they do not recognize the rights of national or social minorities. Therefore, the non-Russians support democracy only inasmuch as it gives freedom to nations"(Kondrashov 2000, 77). This is why Russia's national minorities pushed so hard for the powers that they won for themselves. It was only in a federal system with powerful checks on the ethnic Russians' power that minorities could feel protected. As the largest minority group in the country, the Tatars led the way on this question.

While the Union Republics of the USSR made pushes for independence, nationalist Tatar leadership took that same opportunity for them within Russia. In order to accomplish their objectives Tatar leaders had to play a delicate balancing act between Boris Yeltsin and his reformers and the Communist Party leadership." To resolve the crisis, in April 1990 Gorbachev rushed through the USSR Supreme Soviet a legislation package which was designed to head off the political initiative of the Baltic republics. Its 'carrot' part included concessions of greater powers to the republics in the economic sphere. In order to pass this part without a hitch, Gorbachev had to accommodate the demands of the autonomous republics" (Kondrashov 2000, 101). The Tatar leadership jumped at this opportunity and used their strengthened position to negotiate for broader rights, and in this they were tacitly encouraged by Yeltsin's own work to attain Russian independence from the Soviet Union. At first Yeltsin seemed as though he could be an ally in the nationalists' quest for independence, but it soon became clear that his indulgence of the Tatar nationalists was only for instrumental reasons.

While Yeltsin and Gorbachev were negotiating the federation treaty to be adopted towards Russia and the Soviet Union, Shamiev insisted on participating in negotiations as an equal party as the representative of Tatarstan. "Gorbachev, sensing an ally where before there had been opposition, was encouraging" (Lloyd 1998, 177). Shamiev had previously been a critic of the Soviet government and the ways that the Soviet Union had treated Tatarstan. Knowing that he was unlikely to get a better deal from Yeltsin, Shamiev decided to throw his force with Gorbachev. Knowing that Shamiev could play spoiler, both Yeltsin and Gorbachev accommodated Tatarstan's demands to

3 Russian Census Information, accessed Jan 12, 2010. Current population of Tatars within Tatarstan is roughly 2 million, while ethnic Russians number approximately 1.5 million. 
the extent that they could, working out the federation treaty that is still broadly operated under.

For one thing, Yeltsin was a big blow to the hopes of the nationalists in Tatarstan, since he peeled off a lot of their support by promising democracy. People were willing to give up independence if the seemingly more attainable goal of democracy in Russia and Tatarstan was available (Kondrashov 2000, 138) "At this point, Gorbachev was committed to maintaining central control of eight key policy spheres:

(1) defense and state security;

(2) foreign policy, trade, and customs;

(3) human rights;

(4) a unified monetary policy, prices, and standards;

(5) energy supplies;

(6) transportation;

(7) environmentalregulation; and

(8) scientific and technical progress." (Gleason 1992, 150)

Gorbachev had reached the limit of the freedoms he was willing to grant to troublesome groups like the Tatars, and Yeltsin stepped into that breach. He spoke in Tatarstan of letting the Tatars (and all other minority governments) have broad autonomy in conducting their affairs, even of independence for them. On the one hand, this ensured that he had the support of these people in his struggle against the communist leadership. On the other hand it emboldened nationalist sentiment in these areas and made it difficult for him to maintain Russia's territorial stability once he prevailed in that fight (Kondrashov 2000, 142).

By 1990, Tatarstan had declared its territorial and cultural sovereignty and its leadership made moves to consolidate those gains. The region's strategic importance gave nationalist Tatars a strong hand to play with Yeltsin, and they used it to full advantage." The draft Yeltsin constitution (1992), following through on the summer convention, equalized the status of the federation subjects, converting Russia from an asymmetrical to a symmetrical federation" (Sharlet 1994, 123). This represented a small step backwards for the nationalists from the gains Gorbachev had been willing to accede to, but it was perhaps the best they could have hoped for given Yeltsin's popularity at the start of his administration. The draft constitution eliminated any talk of sovereignty for national republics like Tatarstan, but granted them the ability to control their finances, elect their own leadership, and promote a national culture and language. These were key gains for Tatar nationalists to consolidate.

\section{Religious Friction and Accord}

The religious history of Tatarstan also has helped to ensure continuing peace in the region. The Tatars are the descendents of the Mongol Horde, and for several centuries 
after the Mongols swept across the face of Eurasia the Tatars enjoyed the upper hand in relations with the Russians. While the Tatars certainly were not entirely benevolent rulers, they did share the Mongol temperament towards differing religions; that is, religion was unimportant so long as the necessary tribute was paid on time (Bukharaev $2000,288)$. By the time the Russians turned the tables in the $16^{\text {th }}$ century religious tolerance was hardwired into the Tatar outlook. Despite initial attempts to force conversion upon Tatars and to marginalize them within their region relations were normalized under Catherine the Great, and further liberalization occurred under Alexander II. (Mukhetdinov 2010).

The Tatars adapted their faith to their context,

"The Shariah does not function in Russia, and Orthodox Christians comprise the majority of the population. Muslims should settle into this way of life... This country is no worse and no better than Muslim states, it is simply different. This is our fate and our destiny-- to work out the experience of the true path in these conditions. We cannot be made a Saudi Arabia, and we can hardly become Christian Europe. We are as we are. The date tree does not grow on Russian soil."-Rafael Khakimov (cited in Hahn 1998, 184).

This flexibility has allowed Russians and Tatars to live together in peace since the conquests of Ivan the Terrible. One notable example of the independence of Tatar Muslims was their attitudes towards prayer during the Soviet era. In a break with tradition, Tatar mullahs began to allow women into the mosques to pray with the men during services. This had a dual effect: it brought the Tatar community together, and it made the differences between Tatars and Russian Christians slightly less distinct. The mullahs are also flexible on the aspect of daily prayer. The whole program of religion among Tatars is more relaxed than elsewhere in the Muslim world, largely because of Soviet restrictions (Rorlich 1986, 163).

The relationship between Muslim and Christian clergy is, at the least, cordial. When the Kazan Kremlin was being restored and the Qol Sharrif mosque being rebuilt within the Kremlin walls, Patriarch of Russia Alexei returned to Kazan the most sacred copy of the city's distinctive icon, the Kazan Mother of God. The Tatars saw this gesture as a deeply respectful acknowledgement of Tatarstan and Tatar culture on the part of the Russian Orthodox Church (Vagapova 2010). During the ceremony, the Patriarch emphasized the cooperation that Christian and Muslims within Russia were capable of, saying that such cooperation enabled the groups "to sustain peace in society, to cooperate in preventing moral foundations from being ruined, and to uphold traditional cultural values." (Novosti 2005)Indeed, Damir-Khazra Mukhetdinov, a Tatar Muslim leader in the Nizhny Novgorod Oblast, which borders Tatarstan, states that the relationship with the church is positive. The two groups share similar values between the Bible and the Qur'an; they have solidarity with each other (Mukhetdinov 2010). Gordon Hahn characterizes Tatarstan's official clergy as slightly more conservative 
than the Tatar intelligentsia, but they are also financially dependent upon the government for funding (Hahn 2007, 185).

Relations, however, are not perfect. Mukhetdinov notes that some of the younger Orthodox clergy members have emerged from seminary radicalized, and he also allows that every once in a while, one sees negative speeches about Tatars, for example. Overall, religious people-Russian and Tatar-are generally more tolerant of each other than non-religious people. He does not appreciate work done by the Orthodox Church to proselytize to Muslims, believing that the two religions should not be competing for converts, but rather competing to do good works (Mukhetdinov 2010). In November, a Tatar priest was killed after evening mass, presumably by a Muslim assailant. Father Danil Sysoyev was known for his anti-Muslim stance, and he openly encouraged Muslims to convert to Christianity. He was notorious for comparing Islam with the Communist Party and the Nazis. Muslim leaders condemned the killing, but at least one who preferred to remain anonymous allowed, "He was an odious figure." (The Independent, 2009).

\section{Conclusion: Putin's Federal Reset}

Sometimes the Russian government is the bull in the china shop, creating tension between groups. Mukhetdinov says that the Russian government does not see shades of grey, and he thinks that this is a bad stance for the government to take. The government's deals depend solely on the situation immediately, not based on the future or long-term projections. The government is focused on now. "The government works as a firefighter only at the last possible moment, but they do not engage in any fire prevention. They only respond when things start to burn." Mukhetdinov describes the deals that the government brokers as not "literate" to the situations (ibid. 2010). Additionally, the Russian government had made moves in recent years to claw back some of the control ceded to national republics by Yeltsin. For example, no longer are the Presidents of Autonomous Republics elected by their constituents; rather, they serve at the pleasure of the President in Moscow. This process is unfolding in Tatarstan currently. President Shaimiev is reaching the end of his term, and has announced that he will step down from it in order to let a younger generation of Tatar leadership step forward (St. Petersburg Times 2010) Given the fact that he can only serve if Federation President Medvedev nominates him for another term, it is difficult to see this as anything other than Moscow wanting new blood and giving Shaimiev the chance to bow out gracefully.

While the Russian government has been helpful in allowing that Tatars-like other national minorities - teach their native language in state schools, this has not been an unqualified success. Ethnic Russians within Tatarstan are mostly monolingual since 
they are not encouraged to learn Tatar, meaning that if Tatars wish to do business or communicate with Russians, they must be bilingual. Further trouble arises when it comes time to teach history and culture in Tatarstan. The Russian government has made it mandatory that all children in state schools be given a course in Russian cultural history. By default, this has meant teaching of "Orthodox" culture, as this is considered to be a defining Russian cultural feature. Professor Vagapova says that this requirement would not bother most Tatars if a corresponding class on Russian Muslim culture was taught, but this is forbidden. From Vagapova's point of view, Russia is multicultural, so this stance does not make sense. Islam is also part of Russian culture, so it is wrong to exclude it from the schools, particularly those schools in predominantly Muslim regions (Vagapova 2010).

Another particularly awkward moment occurred when conservative Muslims in Tatarstan protested at the Christian symbols on their passports, and Muslim women demanded to be allowed to wear their headscarves while being photographed for their passports. Muslim authorities intervened in each case, assuring pious Muslims that it was permissible to carry around items with crosses on them so long as the crosses were not being worshipped, and obtaining the right for women to be photographed with their scarves on (BBC 2005). Vagapova meets periodically with cultural and religious leaders in the Nizhny Novgorod region, but Mukhetdinov notes that these groups are few and far between in Russia. From his perspective, it is a shame that Russians are more knowledgeable of Americans and the English than of the minorities within their own country (Mukhetdinov 2010).

Still, Mukhetdinov notes that the serious problems between Tatars and Russians are in the past, and he views Tatar efforts to gain more control over Tatarstan positively (ibid. 2010). As we have seen, a variety of factors are at play in Tatar-Russian relations. Despite many historical reasons for antagonism and numerous small controversies in recent years, the inertia of cultural tolerance between Tatars and Russians has held strong. Buoyed by strong religious commitments to tolerance, broad economic freedom and prosperity for the Tatar minority, and a common Soviet foil, ethnic Russians and Tatars have been able to stay on good cultural terms with each other. Vagapova quoted an old Tatar saying when asked about the prospects of the future, "I'm not good if my neighbor feels bad." Tatars and Russians have lived together in peace for a long time. Of course, all Tatars are different, and all Russians are different; but economics and politics connect them to each other (Vagapova 2010). The Russian government's role in this process is important. Starting from the Soviet period and working forward into the life of the Russian Federation, Russian authorities-- if not always Soviet authorities-- have understood the need to allow for regional autonomy in sensitive areas. Russia does not always get this formula right, as the cases in Chechnya, Ingushetia, and Dagestan show, but Tatarstan can at the very least provide some rough frameworks to begin orienting federalist policies in conflict regions around. 
Up until very recently, Russia's government took a very hands-off approach to Tatarstan, but the recent moves by the government to assert its control over the Republic show that this is changing. These moves probably will not upset the ethnic peace that reigns in the area, but they may engender antipathy towards the central government and embolden Tatar nationalists. In this, Russia, like all federations, faces a difficult balancing act. Federations facing ethnic division can take a lesson from Tatarstan in a number of ways, however. First, Russia and Tatarstan show that ethnic animosity can be overcome. The timetable for this could well be excruciatingly slow, however. Trust is not achieved in a day, or even in an election cycle, so all involved need to demonstrate patience and perseverance. Second, Tatarstan shows that a central government willing to devolve powers to a robust local government can work to diffuse resentment towards those groups in power. Third, non-governmental civil entities need to be encouraged to take up leadership roles within society, and to lay the foundations for ethnic cooperation. This facet has been critical in the development of Tatarstan, with the Jadids taking up this post within Tatar society. Much literature has already been published in this area, but robust civil society cannot develop in a vacuum; it needs the support of surrounding structures in order to work for positive change. 


\section{References}

[1] Akiner, S. 1983,Islamic Peoples of the Soviet Union. Kegan Paul International: London.

[2] Bahry, D. 2005, "The New Federalism and the Paradoxes of Regional Sovereignty in Russia." Comparative Politics. Vol. 37, No. 2. 127-146.

[3] Bennigsen, A. and Lemercier-Quelquejay C., 1967,Islam in the Soviet Union. Pall Mall Press: London. 1967.

[4] BBC Worldwide reporting 2005, "Tatarstan Muslims Refuse Russian Passports over Christian Symbols". Dec. 7.

[5] Bukharaev, R. 2000/slam in Russia: The Four Seasons. Curzon Press: Richmond.

[6] Gleason G. 1992, "The Federal Formula and the Collapse of the USSR." Publius. Vol. 22, No. 3. 141-163.

[7] Hahn. G.M. 2007, Russia's Islamic Threat. Gordon M Hahn. London: Yale.

[8] Hunter, S. T. 2004,Islam in Russia: The Politics of Identity and Security. ME Sharpe, Inc.: New York.

[9] Kondrashov, S., Nationalism and the Drive for Sovereignty in Tatarstan, 198892: Origins and Development. St. Martin's Press, Inc: New York. 2000.

[10] Lloyd, J., Rebirth of a Nation: An Anatomy of Russia. Penguin: London. 1998

[11] Mote, V., Siberia: Worlds Apart. Boulder CO: Westview Press. 1998.

[12] Mukhetdinov, D. K. Interview by author. Nizhny Novgorod, Russia. April 1, 2010.

[13] Novosti, "Patriarch Alexei Says Christian-Muslim Dialogue is a Priority for the Russian Orthodox Church." RIA, July 21, 2005.

[14] Odynova, A. and Bratersky, Al., St. Petersburg Times, "Tatarstan President Quits as Kremlin Revamps Regions." http://www.times.spb.ru/index.php?action_id=2\&story_id=30673, accessed July 27, 2010.

[15] Pelenski, J. Russia and Kazan: Conquest and Imperial Ideology. Mouton: The Hague: 1974.

[16] Rorlich, A-A., The Volga Tatars. Hoover Press: Stanford. 1986.

[17] Russian Census Information, http://www.gks.ru/, accessed June 1, 2010.

[18] Sharlet, R. "The Prospects for Federalism in Russian Constitutional Politics." Publius. Vol. 24, No. 2. 115-127, 1994.

[19] Smith, G. "Russia, Multiculturalism, and Federal Justice." Europe-Asia Studies. Vol. 50, No. 8. 1393-1411, 1998. 
[20] St. Petersburg Times, "Tatarstan President Quits as Kremlin Revamps Regions." Alexandra Odynova and Alexander Bratersky. http://www.times.spb.ru/index.php?action_id=2\&story_id=30673, accessed July 27, 2010.

[21] Vagapova, F. Interview by author. Nizhny Novgorod, Russia. March 26, 2010.

[22] The Independent, London, Walker, S. "Faith Leaders Call for Calm as Murdered Priest is Buried," World, p.18, November 24, 2009. 